\title{
Development of real-time reverse transcriptase-polymerase chain reaction (rt RT- PCR) targeting four genes of peste des petits ruminants virus*
}

\author{
Ender DINÇER ${ }^{1}$, Aykut ÖZKUL ${ }^{2}$ \\ ${ }^{1}$ Mersin University, Advanced Technology, Research and Education Centre, Mersin; ${ }^{2}$ Ankara University, Faculty of Veterinary \\ Medicine, Department of Virology, Dışkapı-Ankara /TURKEY.
}

\begin{abstract}
Summary: In this study, one-step real-time quantitative reverse transcription PCR (qRT- PCR) was developed for the first time and evaluated for detection of peste des petits ruminants virus (PPRV) in field samples obtained from distinct geographical areas of Turkey. Primers and probes targeting four PPRV genes (namely L, M, N and P) were designed based on full genome sequence (AJ849636) of the local isolate (Tu00). The detection limits of the assays were found to be 7 copies/ $\mu \mathrm{L}$ RNA for L, 6 copies/ $\mu \mathrm{L}$ RNA for P, 10 copies $/ \mu \mathrm{L}$ RNA for M and 700 copies/ $\mu \mathrm{L}$ RNA for N, respectively. Besides, the detection ratio for PPRV in 45 field samples was $100 \%$ (45) for L, 88.9\% (40) for M, 77.8\% (35) for P and 22.3\% (10) for N, respectively. In conclution, onestep real-time quantitative reverse transcription PCR (qRT- PCR) assay reported here for L gene design provides rapid, specific and sensitive detection of PPRV in tissue samples obtained from field cases.
\end{abstract}

Key words: Peste des petits ruminants, Real-time qRT-PCR, virus detection.

\section{Küçük ruminant vebasının dört genini hedefleyen gerçek zamanlı reverz - transkriptaz polimeraz zincir reaksiyonu (rtRT - PZR)' nun geliştirilmesi}

Özet: Bu çalışmada, tek basamaklı gerçek zamanlı kantitatif reverz transkripsiyon polimerize zincir reaksiyonu tekniği (qRTPCR) geliştirildi ve Türkiye'nin farklı coğrafik alanlarından elde edilen saha örneklerinde küçük ruminant vebası virusunun (PPRV) tespiti için karşılaştırıldı. Yerel PPRV (Tu00)' nün dört genini (L, M, N ve P) hedefleyen primer ve problar ifade edilen virusun tüm genom dizini (AJ849636) temel alınarak tasarlandı. Çalışma kapsamında gerçekleştirilen tasarımlar ile her testin tespit sınırları, sırasıyla L geni için 7 kopya/ $\mu \mathrm{L}$ RNA; P geni için 6 kopya/ $\mu \mathrm{L}$ RNA; M geni için 10 kopya/ $\mu \mathrm{L}$ RNA ve N geni için 700 kopya/ $\mu \mathrm{L}$ RNA olarak bulundu. Bunun yanında, 45 saha örneği kullanılarak yapılan tanısal değerlendirmelerde ise virus genomunun tespit oranları sırasıyla L geni için \%100 (45); M geni için \%88.9 (40); P geni için \%77.8 (35) ve N geni için \%22.3 (10) olarak bulundu. Sonuç olarak, L geni dizaynı için bildirilen tek basamaklı gerçek zamanlı kantitatif reverz transkripsiyon polimerize zincir reaksiyonu deneyi (qRT-PCR) saha vakalarından elde edilen doku örneklerinde hızlı, spesifik ve hassas PPRV tespitini saplamıştır.

Anahtar sözcükler: Küçük ruminant vebası, Gerçek zamanlı RT-PZR, virus tespiti.

\section{Introduction}

Peste des petits ruminants virus (PPRV) is a highly contagious, acute, febrile illness causing major economic losses small ruminant production and threatening agricultural balance in developing countries, including those in Africa, the Arabian Peninsula, the Middle East and Southeast Asia (Kwiatek et al. 2010; Batten et al. 2011). PPRV affects two small ruminants, namely sheep and goats, as a main host, but a large variety of ruminant species can also be susceptible to the infection (Albayrak and Gur 2010). PPRV has a close antigenic relationship with rinderpest virus (RPV) in cattle, canine distemper virus (CDV) in dogs and phocine distemper virus (PDV) in seals (Kwiatek et al. 2010). Mortality and morbidity is very high in naive animal populations, sometimes reaching rates of 90-100\% (Albayrak and Gur 2010; Batten et al. 2011; Gurcay et al. 2013). PPRV infection is characterized by increased body temperature, anorexia, necrotic stomatitis, gastrointestinal symptoms like diarrhea, and inflammation of the respiratory tract (nasal and ocular discharges) (Ozkul et al. 2002).

PPRV is a Morbillivirus of the Paramyxoviridea family. Members of the Morbillivirus genus have a single-stranded, non-segmented negative sense RNA genome that encodes eight proteins, including a nucleocapsid protein $(\mathrm{N})$, phosphoprotein $(\mathrm{P})$, matrix

\footnotetext{
* This manuscript was prepared partly from the $\mathrm{PhD}$ thesis of the first author.
} 
protein $(\mathrm{M})$, fusion protein $(\mathrm{F})$, haemagglutinin protein $(\mathrm{H})$, large polymerase protein $(\mathrm{L})$ and two nonstructural accessory proteins ( $\mathrm{C}$ and $\mathrm{L}$ ), which are produced by the RNA editing mechanisms of the $\mathrm{P}$ gene (Batten et al. 2011).

PPR is a trans-boundary disease that causes major economic problems in developing countries. Because of its devastating economic impact, rapid and effective diagnosis of PPRV is very important in the field. A variety of diagnostic laboratory methods are used for confirming the presence of PPRV. For example, serologic detection methods, such as ELISA for PPRV, can be used to obtain antiviral antibodies, although this assay is laborious and time-consuming (Grant et al. 2009; Batten et al. 2011). Cell culture is also labor intensive and troublesome, rendering it unsuitable for routine diagnostic purposes. Recently, conventional RT-PCR for PPRV detection has been developed as an accurate and specific diagnostic tool. However, conventional RT-PCR has disadvantages. For example, it needs agarose gel running of products for detection and differentiation of PCR products and is not convenient for quantitation purposes. The closed system of real-time qRT-PCR not only has much lower risk of contamination than conventional RT-PCR but also allows quantitative detection of amplified DNA products. Therefore, realtime qRT-PCR techniques have been developed for detecting PPRV for diagnostic purposes (Bao et al. 2008). N gene sequence has been chosen for real-time qRT- PCR because it is better conserved and more expressed than other genes (Kwiatek et al. 2010; Batten et al. 2011). In addition, $N$ gene directed real-time qRTPCR was used to detection of marine morbilliviruses, including dolphin and porpoise viruses (Grant et al. 2009).

The aim of this study was to develop reliable and sensitive real-time qRT-PCR targeting four different genes (L, M, N and P) for detection and quantification of PPRV. In addition, the diagnostic ability of the test systems was evaluated in samples taken from naturallyoccurring PPRV-suspected cases.

\section{Materials and Methods}

Field specimens and nucleic acid extraction: In this study, tissue samples, including liver, tongue, lien, lungs and blood, were collected from 45 sheep and goats suspected of PPR disease from various localities in Turkey. Genomic RNAs (gRNA) were isolated from tissue samples using High Pure Viral RNA kit (Roche, Germany) and were kept at $-80{ }^{\circ} \mathrm{C}$ until use. Tissue samples from 15 healthy animals slaughtered in local abattoirs were included the study as disease negative control samples.

Primers/probe designs and real-time qRT-PCR: The real-time qRT-PCR primers and probes were designed based on the nucleotide sequence of local PPRV strain (Turkey 2000-Tu00; GenBank accession no. AJ849636) using CLC Bio Main Work Bench v5.2 (Table 1).

Positive PPRV RNA from cell culture-adapted local isolate was used for optimization of the test protocol. The reaction mixture was prepared in $25 \mu \mathrm{L}$ using QuantiTect Probe qRT- PCR kit (Qiaqen, Germany) and contained

Table 1. Primers/probe sets used in real-time qRT-PCR. All designs were prepared based on the genome sequence of PPRV local isolate Tu00 (GeneBank Accession \# AJ849636). * indicates Virus name/Gene/Direction/Localization.

Tablo 1. Kantitatif gerçek zamanlı RT-PZR'nunda kullanılan primers/prop dizinleri. Tüm tasarımlar PPRV'nun lokal izolatı Tu00 (GeneBank Accession \# AJ849636) '1n genom dizinine temel alınarak hazırlandı. * Virus ismi/Gen/Yön/lokalizasyonu belirtir.

\begin{tabular}{lll}
\hline Primer/Probe Name* & Sequences $\left(5^{\prime} \rightarrow 3^{\prime}\right)$ & Modification \\
\hline PPRV/M/F/4186 & TGGGAGGAATAGGTGGAA & \\
PPRV/M/R/4362 & GGACGGCTTGGATTTTGA & \\
PPRV/M/Prb & AGAAGCACCGGGAAAATGAG & \\
PPRV/N/F/350 & AGAGTCACCCGGGCAATTGATACA & 'TAMRA \\
PPRV/N/R/646 & TTGGCCAGAAGGATCCAGACTTGT & \\
PPRV/N/Prb & TTGACCTTTGCATCACGTGGTGCTGA & \\
PRV/P/F/3067 & ATTGGAACCAAAGCCAACTCCAGC & \\
PPRV/P/R/3329 & TGCTTGGCGAGAATTGCTGTTAGC & \\
PPRV/P/Prb & AAGCTCTGCAATCGGGTTTGTCCCAT \\
PPRV/L/F/10054 & GCCGAGTCAGATACTTGTGGGAT & \\
PPRV/L/R/10134 & GCAGGGCAACAACTTGGTA & \\
PPRV/L/Prb & TGGGTTCTTCCCAACACTAGGCA 3'TAMRA \\
\hline
\end{tabular}


200ng $(\max 5 \mu \mathrm{L})$ extracted gRNA, $12,5 \mu \mathrm{L} 2 \times$ reaction buffer, $0,25 \mu \mathrm{L}$ RT enzyme mix, 5 pmol probe, and 10 pmol of forward and reverse primers. Amplification and detection stages were performed in Rotorgene 6000 (Qiagen, Germany). Thermal cycling conditions were as follows: $50{ }^{\circ} \mathrm{C}$ for $30 \mathrm{~min}$ for reverse transcription, $95^{\circ} \mathrm{C}$ for $15 \mathrm{~min}$ for initial denaturation followed by 40 cycles of denaturation at $94{ }^{\circ} \mathrm{C}$ for $15 \mathrm{sec}$, annealing at $53{ }^{\circ} \mathrm{C}$ for $\mathrm{L}$ gene, $60{ }^{\circ} \mathrm{C}$ for $\mathrm{M}, \mathrm{P}$ and $\mathrm{N}$ genes $1 \mathrm{~min}$. Fluorescence was collected at the annealing phase of each cycle. To determinate intra- and inter- assay variability, RNA samples were analyzed in two replicates per run. Mean $\mathrm{C}_{\mathrm{T}}$ values, standard deviations (S.D.), and coefficients of variation $(\mathrm{CV})$ were calculated.

Preparation of the RNA standard: A standard curve was created using purified gRNA of passage 85 (p85) PPRV grown in Vero cells, with a known infectivity titer (Figure 1). Stock PPRV was treated with RNaseA $(20 \mathrm{mg} / \mathrm{ml}$; Thermoscientific, USA) for $30 \mathrm{~min}$ at room temperature in order to eliminate all free RNAs. Ten-fold serial dilutions (ranging from $1 / 10$ to $1 / 10^{6}$ ) of virus were prepared in a total of $200 \mu \mathrm{L}$ of Dulbeccoc's Minimum Essential Medium (DMEM, Biochrom, Germany). PPRV gRNA isolation in dilution steps was performed using High Pure Viral RNA kit (Roche, Germany), with RNAs eluted in $30 \mu \mathrm{L}$ of TE buffer. Finally, eluted RNAs were quantitated with microliter spectroscopy (Picodrop, UK).
A

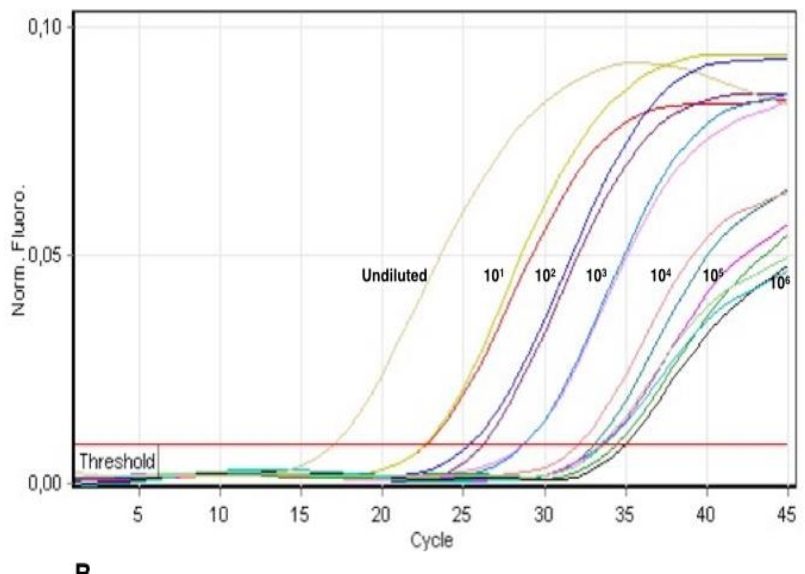

B

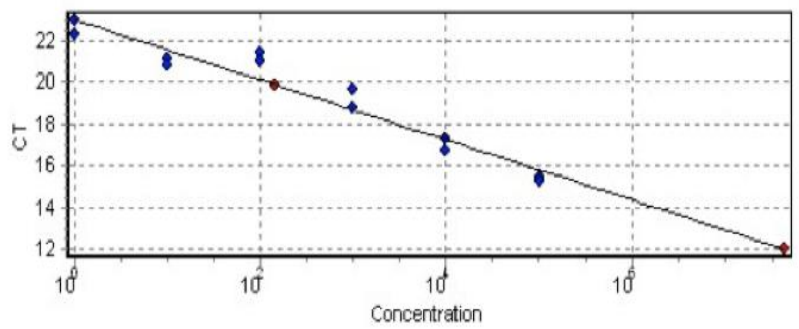

Fig 1. Detection limit and standard curve of real-time qRT-PCR targeting L gene. (A) Amplification of 10-fold serial dilutions of gRNA of PPRV at p85 revealed between 2.3 and $2.3 \times 10^{6}$ copies/mL. (B) The standard curve formula is $y=-3.349+$ 36.567. The correlation coefficient $\left(\mathrm{R}^{2}\right)$ is 0.997 .

Şekil 1. L gen bölgesini hedefleyen kantitatif gerçek zamanlı RT-PZR' nin standart eğrisi ve tespit sınırları. (A) P85'deki PPRV'nün gRNA'sının 10 katlı seri sulandırmalarının amplifikasyonu 2.3 ile $2.3 \times 10^{6} \mathrm{kopya} / \mathrm{mL}$ arasinda gerçekleşti. (B) Standart eğri formülü y $=-3.349+36.567$ ' dir. Korelasyon katsayıs1 $\left(\mathrm{R}^{2}\right)$ 0.997'dir.

Table 2. Intra-assay variability and inter-assay reproducibility of the PPRV real-time qRT-PCR assay, $\mathrm{C}_{\mathrm{T}}$ values, amplicon size and positivity rates of gene designs (S.D.: standard deviation; CV coefficient of variation).

Tablo 2. PPRV kantitatif gerçek zamanlı RT-PZR'nun deney içi değişkenliği ve deneylar arası verimliliği, $\mathrm{C}_{\mathrm{T}}$ değerleri, ürün büyüklüğ̈̈ ve gen tasarımlarının pozitiflik oranları (S.D.: standart sapma; CV değişim katsayısı).

\begin{tabular}{|c|c|c|c|c|c|c|}
\hline & \multirow{2}{*}{$\begin{array}{c}\text { RNA } \\
\text { Copies }\end{array}$} & \multicolumn{2}{|c|}{ CT value } & \multirow{2}{*}{ Mean Ct } & \multirow{2}{*}{$\begin{array}{l}\text { S.D. } \\
( \pm)\end{array}$} & \multirow{2}{*}{$\mathrm{CV}(\%)$} \\
\hline & & $\operatorname{Max}$ & Min & & & \\
\hline & $2,2 \times 10^{6}$ & 15,46 & 15,25 & 15,34 & 0,08 & 0,52 \\
\hline Intra-assay & $2,2 \times 10^{5}$ & 16,67 & 17,27 & 16,80 & 0,29 & 1,72 \\
\hline \multirow[t]{4}{*}{ Variability } & $2,2 \times 10^{4}$ & 19,63 & 18,71 & 19,08 & 0,51 & 2,67 \\
\hline & $2,2 \times 10^{3}$ & 21,43 & 21,03 & 21,25 & 0,16 & 0,75 \\
\hline & $2,2 \times 10^{2}$ & 21,08 & 20,08 & 20,76 & 0,68 & 3,21 \\
\hline & $2,2 \times 10^{6}$ & 15,60 & 15,32 & 15,46 & 0,08 & 0,51 \\
\hline Inter-assay & $2,2 \times 10^{5}$ & 16,30 & 17,03 & 16,66 & 0,27 & 1,62 \\
\hline \multirow[t]{3}{*}{ Reproducibility } & $2,2 \times 10^{4}$ & 19,50 & 18,75 & 19,12 & 0,47 & 2,47 \\
\hline & $2,2 \times 10^{3}$ & 21,40 & 21,09 & 21,24 & 0,13 & 0,61 \\
\hline & $2,2 \times 10^{2}$ & 21,15 & 20,13 & 20,64 & 0,63 & 3,05 \\
\hline Target Gene & $\mathrm{C}_{\mathrm{T}}$ values & Detection lir & t (copy/ $\mu \mathrm{L})$ & Amplicon size (bp) & \multicolumn{2}{|c|}{$\begin{array}{c}\text { Positive }(\%) \text { in natural PPR } \\
\text { infection }\end{array}$} \\
\hline $\mathrm{L}$ & 19,38 & \multicolumn{2}{|c|}{7} & 80 & \multicolumn{2}{|c|}{100} \\
\hline M & 18,84 & \multicolumn{2}{|c|}{10} & 176 & \multicolumn{2}{|c|}{88,9} \\
\hline $\mathrm{P}$ & 28,98 & \multicolumn{2}{|c|}{6} & 272 & \multicolumn{2}{|c|}{77,7} \\
\hline $\mathrm{N}$ & 22,18 & \multicolumn{2}{|c|}{700} & 296 & \multicolumn{2}{|c|}{22,3} \\
\hline
\end{tabular}




\section{Results}

Sensitivity and reproducibility of real-time $q R T$ PCR designs: Each primers/probe design produced relevant amplicons of 80, 176, 272 and 296 bp for the L, $\mathrm{M}, \mathrm{P}$ and $\mathrm{N}$ gene regions, respectively, at the end of the real-time qRT-PCR PPRV gRNA cycles (Table 2). The assay was able to detect viral RNA concentrations of 7, 6, 10 and 700 copies/ $\mu \mathrm{L}$ RNA for the L, P, M and N genes, respectively. The lowest $\mathrm{C}_{\mathrm{T}}$ values observed were 19.38, 18.84, 28.98, and 22.18 for the L, M, N and $\mathrm{P}$ genes, respectively (Table 2). Standard curves were calculated using 10-fold serial dilutions of gRNA of PPRV (p85). Since the most sensitive results were detected with $\mathrm{L}$ gene design, these data are presented in Figure 1) which shows the linear detection limits of the assay. There was a linear relationship between $\mathrm{C}_{\mathrm{T}}$ values and RNA concentration within a range of 2.3-2.3 $\times 10^{6}$ (Figure 1). An Intra-assay CV of $0.52-3.21 \%$ was found, while the inter-assay $\mathrm{CV}$ was between 0.51 and $3.05 \%$ (Table 2). The real-time qRT-PCR was able to detect viral gRNA concentrations as low as 6 copies per reaction for $\mathrm{P}$ gene. The linear detection limits of each design are presented in Table 1 . The earliest $\mathrm{C}_{\mathrm{T}}$ value (18.84) was observed with the $\mathrm{M}$ gene-specific primers/probe design, while the latest $\mathrm{C}_{\mathrm{T}}$ (34.73) was seen with the $\mathrm{N}$ gene-targeted primers/probe design.

$P P R V$ genome detection in field specimens: Each primers/probe design produced the expected amplicons at the end of the real-time qRT-PCR cycles carried out with PPRV gRNA in sizes of 80, 176, 272 and 296 bp for L, $\mathrm{M}, \mathrm{P}$ and $\mathrm{N}$ gene regions, respectively (Table 2). Out of 45 field samples, all samples $(100 \%)$ were positive with the L-based design, 40 (88.9\%) with the M-based design, $35(77.8 \%)$ with $\mathrm{P}$ and $10(22.3 \%)$ with $\mathrm{N}$ directed primers and probe design.

\section{Discussion and Conclusion}

Peste des petits ruminant (PPR) is a devastating disease of small ruminants that causes significant economic losses. However, detection of PPRV in field samples, early diagnosis and preventive measures can reduce these effects (Diallo et al. 1995) so rapid, sensitive, specific and reliable methods are required for PPRV detection. Cell culture isolation is time-consuming and laborious, making it unsuitable for routine diagnosis. Instead, ELISA and a variety of RT-PCR diagnostic methods have been developed (Kwiatek et al. 2010). More specifically, RT-PCR assays have been widely used to detect $\mathrm{F}, \mathrm{N}$ and $\mathrm{P}$ gene regions in PPRV (Couacy-Hymann et al. 2002; Balamurugan et al. 2006), and the highly conserved $\mathrm{F}$ gene region in marine morbilliviruses (Barett et al. 1993; Saliki et al. 2002). Recently, real-time qRT-PCR has been become popular for detecting viruses of the Paramyxoviridea family
(Grant et al. 2009). The new generation of real-time qRT-PCR has more advantages than conventional techniques. First, since amplification and analysis are performed in a closed system, contamination risks are very low. Second, it is more rapid, sensitive and reproducible. Abera et al. (2014) have developed the SYBR Green I based RT- PCR assay for detection of PPRV in field samples targeting the $\mathrm{N}$ gene. Morbillivirus $\mathrm{N}$ protein has two parts: a highly conserved amino terminal, and a highly variable carboxyl terminal (Kwiatek et al. 2007; Bao et al. 2008). TaqMan probes designed against the variable region of the $\mathrm{N}$ protein have been used for distinguishing PPR from rinderpest viruses. However, primers/probe designs located in this region showed mismatch problems (Kwiateket al. 2010). Similar complications were reported after RT-PCR applications with TaqMan primers/probe for rabies (Hughes et al. 2004) and bluetongue (Jimenez-Clavero et al. 2006) viruses.

The one-step real-time qRT-PCR assay was able to perform quantitation over a wide dynamic range, from $2.3-2.3 \times 10^{6}$ RNA copies per reaction mixture. The minimum detection limit was 2.3 RNA copies per reaction mixture, with $\mathrm{C}_{\mathrm{T}} 35.06 \pm 1.00$ for the $\mathrm{L}$ gene region. Bao et al. (2008) and Abera et al. (2014) found a detection limit 8.1 RNA copies per reaction mixture, with $C_{\mathrm{T}} 37.26 \pm 1.27$ and 5.11 copies per reaction mixture, with $33.67 \pm 0.5$ for the $\mathrm{N}$ gene region. These results showed that designs based on the $\mathrm{L}$ gene region detected PPRV RNA more specifically and effectively.

In this study, a one-step real-time qRT-PCR method targeting four different genes (L, M, N and P) was evaluated for its ability to detect the PPRV genome in field samples. There were problems with the ability of primers/probe designed to detect the $\mathrm{N}$ gene region to detect PPRV RNA. This can be explained by high sequence variation in the region targeted by the primers/probe. The gRNA detection rate for the $\mathrm{N}$ design was lower than the other designs (L, M and P), which confirms previous studies (Hughes et al. 2004; JimenezClavero et al. 2006). All of 45 field samples were detected as positive with the L-gene focused design, 40 with the $\mathrm{M}$ gene design, 35 with $\mathrm{P}$ and 10 with $\mathrm{N}$. The amplicon sizes from the $\mathrm{L}, \mathrm{M}, \mathrm{N}$ and $\mathrm{P}$ genes were 80 , 176, 272 and 296, respectively. In general, small amplicon size gives more effective results. It has been demonstrated that the $50 \mathrm{bp}$ amplicon size for the $\mathrm{N}$ gene detects PPRV more sensitively and reliably (Kwiatek et al. 2010). In addition, real-time $\mathrm{qPCR}$ primers for measles virus designed as $67 \mathrm{bp}$ amplicon size give better results in field sample diagnoses (Thomas et al. 2007). In our study, the size of the $\mathrm{N}$ gene amplicon was greater than those obtained from other genes (L, M and P). This result may be another reason explaining the lower rate of 
true positives in field samples. The $\mathrm{L}$ design had the highest rate in the four regions, detecting PPRV gRNA in all field samples. This result shows that small amplicon size allows more efficient detection of PPRV RNA in field samples. Real-time qRT-PCR results may be affected by a variety of factors, such as the genomic region focused on, length of region amplified and sample storage conditions. Although RNA is very sensitive to a variety of conditions, such as freezing, thawing, heat and mechanical factors, this study showed that RNA samples kept at $-80{ }^{\circ} \mathrm{C}$ for up to one year remaining sufficiently stable to be used effectively for real- time qRT- PCR.

In conclusion, our study made three main findings: (a) the $\mathrm{L}$ gene design provides the greatest diagnostic value across the four different genes targeted to detect PPRV in real-time qRT- PCR; (b) as amplicon size increases, detection of RNA of PPRV by real-time qRTPCR decreases; (c) for reproducible results in real-time qRT-PCR, amplicon size should be approximately $100 \pm 20 \mathrm{bp}$.

\section{References}

1. Abera T, Thangavelu A, Chandran JDN, et al (2014): A SYBR Green I based real- time RT-PCR assay for specific detection and quantitation of Peste des petits ruminants virus. Vet Res, 10, 1-8.

2. Albayrak H, Gür S (2010): A serological investigation for Peste des petits ruminants infection in sheep, cattle and camels (Camelus dromedarious) in Aydin province, West Anatolia. Trop Anim Health Pro, 42, 151-153.

3. Balamurugan V, Sen A, Saravanan P, et al (2006): Onestep multiplex RT-PCR assay for the detection of the peste des petits ruminants virus in clinical samples. Vet Res Commun, 30, 655-666.

4. Bao J, Li L, Wang Z, et al (2008): Development of one-step real-time RT-PCR assay for detection and quantitation of peste des petits ruminants virus. J Virol Methods, 148, 232-236.

5. Barrett T, Romeo CH, Baron MD, et al (1993): The molecular biology of rinderpest and peste des petits ruminants. Ann Med Vet, 137, 77-85.

6. Batten AC, Banyard CA, King PD, et al (2011): A realtime RT-PCR assay fort the specific detection of Peste des petits ruminants virus. J Virol Methods, 171, 401-404.

7. Couacy - Hymann E, Roger F, Hurard C, et al (2002): Rapid and Sensitive detection of the peste des petits ruminants virus by polymerase chain reaction assay. $\mathrm{J}$ Virol Methods, 100, 17- 25.
8. Diallo A, Libeau G, Couacy-Hymann E, et al (1995): Recent developments in the diagnosis of Rinderpest and Peste des petits ruminants. Vet Microbiol, 23, 307-317.

9. Grant JR, Banyard AC, Barrett T, et al (2009): Realtime RT-PCR assays for rapid and differential detection of dolphin and porpoise morbillivirus. J Virol Methods, 156, 117- 123.

10. Gulyaz V, Celen N, Ozkul A (2005): The isolation of $P P R$ virus and pathogenicity and attenuation studies on vero cell culture Pendik Vet Mikrobiyol Derg, 36, 1-2.

11. Gurcay M, Kizil O, Baydar E (2013): Peste Des Petits Ruminants (PPR) Virus infections in goats in the Eastern Anatolia of Turkey. Kafkas Univ Vet Fak Derg, 19, 93- 98.

12. Hughes GJ, Smith JS, Hanlon CA, et al (2004): Evaluation of a TaqMan PCR assay to detect rabies virus RNA: Influence of sequence variation and application to quantitation of viral loads. J Clin Microbiol, 42, 299-306.

13. Jimenez - Clavero MA, Aguero M, San Miguel E, et al (2006): High throughput detection of bluetongue virus by a new real-time fluorogenic reverse transcription polymerase chain reaction: application on clinical samples from current Mediterranean outbreaks. J Vet Diagn Invest, 18, 7-17.

14. Kwiatek O, Minet C, Grillet C, et al (2007): Peste des petits ruminants (PPR) outbreak in Tajikistan. J Comp Pathol, 136, 111-119.

15. Kwiatek O, Keita D, Gil P, et al (2010): Quantitative one-step real-time RT-PCR for the fast detection of the four genotypes of PPRV. J Virol Methods, 165, 168-177.

16. Ozkul A, Akca Y, Alkan F, et al (2002): Prevalance, Distribution, and Host Range of Peste des petits ruminants virus, Turkey. Emerg Infect Dis, 8, 708-712.

17. Saliki JT, Cooper EJ, Gustavson JP (2002): Emerging morbillivirus infections of marine mammals: development of two diagnostic approaches. Ann NY Acad Sci, 969 5159.

18. Thomas B, Beard S, Jin L, et al (2007): Development and Evaluation of a Real- time PCR Assay for Rapid Identification and Semi-Quantitation of Measles. J Med Virol, 79, 1587-1592.

Geliş tarihi: 13.06.2014/ Kabul tarihi: 24.10.2014
Address for correspondence:
Ender Dinçer DVM, PhD
Mersin University,
Advanced Technology, Research, and Education Centre, (MEITAM), Çiftlikköy, 33343, Mersin, TURKEY
e-mail: enderdin@gmail.com 